AGRICULTURE AND BIOLOGY JOURNAL OF NORTH AMERICA

ISSN Print: 2151-7517, ISSN Online: 2151-7525, doi:10.5251/abjna.2013.4.2.132.136

(C) 2013, ScienceHuß, http://www.scihub.org/ABJNA

\title{
Sero-epidemiologic survey of the equine arteritis in the region of Khenchela (Algeria)
}

\author{
Dr EI Hacene BERERHI 1, Dr Rachid KABOUIA 1, Dr Omar BOUAZIZ1
}

\author{
Laboratory Management The Animal Health and Production \\ Institute of Veterinary Science Constantine \\ University Constantine1
}

\begin{abstract}
The aim of this study is to evaluate the prevalence of respiratory infections of viral origin in equines .In this perspective we have researched ant viruses antibodies in equine's arteritis in 95 horses of different breeds, Arab-Barb and Barb, all stationed in the region of Khenchela (Kais),located in the north east of Constantine. The animals are prealably recognized, upon a clinical exam, in a good health. They have received a diet containing barley and hay. They are of different sexes and their age is varying between 2 and 10 years old. The equines play an important socioeconomic role. In several rural areas, equines are regularly used as a tensile force for the animal traction cultivation and transport of persons and goods. They thus contribute widely to the increase of agricultural production and the improvement of socio economic conditions of rural populations. The results demonstrate that among the 95 serums tested, 25 were positive $(33,33$ percent).to the reaction serum seroneutralization. These results are discussed in relation whith those observed by other authors.
\end{abstract}

Key-words: Horse, arterits virus, serum neutralization, epidemiology.

\section{INTRODUCTION}

Viral arteritis is a specific contagious equine disease. It often leads to mass abortions and respiratory disorders in livestock and causes significant economic losses. (Chabchoub 1994; Timoney and al., 1991; Timoney and al., 1993; Timoney, 2000a; Zientara and al., 1998).

In 1984, an outbreak of arteritis occurred in the State of Kentucky, United States (Timoney, 1984) and since that, the number of reported outbreaks has increased dramatically worldwide (Holyoak and al., 1993; Hullinger and al. , 2001; Ibn Amor, 1993; Lahlou, 1977; Monreal and al., 1995; Ouahma 1987; Timoney and al., 1986; Zientara and al., 1998. In Tunisia and Morocco, sero-epidemiological surveys have shown a lower circulation of viral arteritis in equine herd (choura, 1986; Ellouze 1980; Chabchoub and al., 2002; Lahlou, 1977). Abortion cases whose origin has not been certainly identified have been reported in the mare (Cole and al., 1986; Balasuriya and al., 1998). Thus, due to the severity of the infection and to the lack of information on the epidemiological situation of this disease,, a seroepidemiological survey in order to evaluate the rate of infection of viral arteritis horses in the region of Khenchela.

\section{MATERIALS AND METHODS}

\section{Material}

Surveyed population: The sero-epidemiological survey was conducted from January 2001 to March 2002, and concerned a herd of 95 horses. They belong to traditional breedings with usually a middle level of hygiene and sanitation. There is no program, neither a vaccination plan to fight against this outbreak, except for rabies and equine influenza. These animals are subject to an irregular medical care. There are also work horses, used in traction and agricultural work in rural areas. The equine population is unequally distributed in this region, where there are a large number of Barb and ArabianBarb. This area has not infrastructures such as studs, horse clubs or racetracks. The geographical features of the equine population in this region, led us to choose the region of Kais, in the north-east of the country, to realize our sero-epidemiological survey.

Samples: The sample was obtained by stratified randomization in the region. Geographical distribution of tested horses was similar to the population 
distribution according to breeds and farming mode. In the region of Kais, horses are predominantly ArabianBarb and Barb breed. The targeted herd was divided into two homogeneous groups from which, the horses was selected and chosen to be tested.

Animals: Our study focused on a herd of 95 horses of different breeds, Arabian-Barb and Barb, they are of different sexes with age ranging from 2 to 10 years. Our survey was conducted with the collaboration of the veterinary services of the Wilaya. These animals did not show obvious clinical signs outstanding respiratory problems, abortions. Breeds and sexes of these horses are shown in Table 1.

Table 1. Race, sexes and number of horses tested

\begin{tabular}{|l|c|c|c|}
\hline Breed & Number & Male & Female \\
\hline $\begin{array}{l}\text { Arabian- } \\
\text { Barb }\end{array}$ & 51 & 16 & 35 \\
\hline Barb & 44 & 14 & 30 \\
\hline \multicolumn{1}{|c|}{ Total } & 95 & 30 & 65 \\
\hline
\end{tabular}

\section{Methods}

Samples: The blood samples were withdrawn from the jugular vein from each animal into vacutainers tubes of $20 \mathrm{ml}$. After centrifugation, $4 \mathrm{ml}$ of serum were collected in bottles of $10 \mathrm{ml}$. They were immediately frozen and stored at- $20^{\circ} \mathrm{C}$ until analysed by the technique of sero-neutralization in microplate on vero cells in monolayer. This is a reference method widely used for the diagnosis of equine viral arteritis (Balasuriya and al., 1997; Senne and al., 1985; Timoney, 2000b).

It should be remembered that neutralizing antibodies revealed persist after infection for several years and furthermore might be present throughout all the lifetime of the animal. It detects immunoglobulin $G$ $(\lg G)$ associated to the neutralization of the equine arteritis virus, representing indicators of an acquired immunity due to previous infection (Zientara and al., 1998; Moraillon and al.,1974; Newton and al., 1999; Ouahma 1987; Timoney and al., 1987).Vero cells form a continuous cell line endowed with an unlimited potential of growth. They are epithelial cells of monkey's kidney used in a single layer for the isolation and the identification of the virus. Bacyrus strain of equine arteritis virus used was provided by the French Agency for Food Safety (AFSSA). The sero neutralization allows the detection of specific antibodies against the equine arteritis virus in the sera of horses taken. Serum is positive when it inhibits the cytopathic effect of the virus at a dilution greater than 1/10. (Fukunaga and al., 1994; Ghram and al., 1994; Moraillon and al., $1978 \mathrm{a}$ and b; Timoney, 2000).

\section{RESULTS}

Among the 95 horses tested, 25 were positive $(33,33$ percent .Cent). In the region of Kais, 8 horses Barb on 44 (or 18.18 percent. Cent) and 17 Arabian-Barb horses of 51 (33.33 percent. Cent) were positive. Table 2.

Table 2. Sera tested positive by animal breed

\begin{tabular}{|l|c|c|c|}
\hline $\begin{array}{l}\text { Animal } \\
\text { breed }\end{array}$ & $\begin{array}{c}\text { Serum } \\
\text { number }\end{array}$ & $\begin{array}{c}\text { Positive } \\
\text { serums }\end{array}$ & $\%$ \\
\hline Barb & 44 & 8 & 18,18 \\
\hline $\begin{array}{l}\text { Arabian- } \\
\text { Barb }\end{array}$ & 51 & 17 & 26.31 \\
\hline Total & 95 & 25 & 33.33 \\
\hline
\end{tabular}

Among the 25 positive samples, 12 had serum titers of positive neutralizing antibody at $1 / 20,7$ positive titres of $1 / 40,2$ positive titres at $1 / 80$ and 4 positive titles of $1 / 160$.

The results based on the sexe of the animals are shown in Table 3.

Table 3. Distribution of sera tested positive by sex horses tested

\begin{tabular}{|l|l|l|l|}
\hline Sexe & $\begin{array}{l}\text { Tested } \\
\text { serums }\end{array}$ & $\begin{array}{l}\text { Positive } \\
\text { serums }\end{array}$ & Rate \% \\
\hline Males & 30 & 4 & 13.33 \\
\hline Females & 65 & 21 & 32.30 \\
\hline Total & 95 & 25 & 26.31 \\
\hline
\end{tabular}

The results indicate that the variation in the rate of infection sexe of the animals is as follows: 
Of the 30 males, 4 were positive, a positive rate of 13.33 percent. Cent. Among 65 females, 21 were positive, a positive rate of 32.30 percent. cent. Considering the age in Table 4.

Table 4. Number of tested positive serums according to age

\begin{tabular}{|l|c|c|c|}
\hline Age Nb. & $\begin{array}{c}\text { Number of } \\
\text { tested } \\
\text { serums }\end{array}$ & $\begin{array}{c}\text { Positive } \\
\text { serums }\end{array}$ & $\begin{array}{c}\text { Positivity } \\
\text { rate\% }\end{array}$ \\
\hline$<2$ years & 15 & 0 & 0 \\
\hline $4-6$ years & 30 & 7 & 23.33 \\
\hline $\begin{array}{l}8-10 \\
\text { years }\end{array}$ & 50 & 18 & 36.00 \\
\hline Total & 95 & 25 & 26.31 \\
\hline
\end{tabular}

We have noted that the animals under 2 years were negative, while those aged from 4 to 6 years have a lower positivity (23.33 percent. cent) and animals with an age ranging from 8 to 10 years The positivity rate is (or 36.00 percent. cent).

\section{DISCUSSION}

The survey revealed an overall seropositivity of 26.31 percent. Cent. The results were comparable to those obtained in Tunisia in 1980 by Ellouze with a positivity rate of 30 percent. cent over 137 tested horses and by Chabchoub and Landolsi in 2002 in Tunisia with 25.62 percent of positivity over 199 horses races, of different sexe and ages. Lahlou in 1977 in Morocco and Ghram and al., 1994 in Tunisia found a seropositivity of 23.33 percent.cent and 17.23 percent. However, these results were still higher than those obtained by Choura in 1986 and Ibn Amor in 1993 in Tunisia, which revealed the seroprevalence of p.cent 9.95 in a herd of 201 horses and 8.75 p.cent of 400 horses respectively. The 76 p. Cent of the tested horses have low serum titres (less or equal to the 40th).

These low positivity rate would be explained by a previous circulation of arteritis virus in this region. Some authors reported that the immune response varied depending on the infecting strain and that the serum titers increased to very high levels after recent infection, then decreased drastically, but persisted longtime after (Fukunaga and al., 1994).
Moreover, in our study, all horses did not show any significant clinical expression and also horses less than 2 years were negative. These results were similar to those reported in 2002 by Chabchoub and al. In Tunisia., authors such as (Cardwell and al., 2002; Choura 1986, Del Piero, 1997 and Moraillon and al., 1978) showed positivity rates significantly lower in old individuals aged less than 2 years. The samples were taken in one kind of traditional farming. The animals lived in middling sanitary conditions, without any program to fight epizootic diseases or vaccination protocols.

El Harrak and al., 1996 in Morocco and Ellouze in 1980 , in Tunisia, noted a high positivity rate in studs in comparison to horses living individually. These authors explained that by the large contagiosity during sporting events. For both breeds (ArabianBarb and Barb) no significant difference. These results are not in agreement with those reported by Ghram and al., 1994 in Tunisia and Moraillon and al.,1978 in Morocco. The same authors noticed the existence of a positive correlation between breed and arteritis virus, with a high seropositivity in Barbs and Arabian-Barbs to that observed in Thoroughbreds. Our investigation showed a significant difference according to sexe. These results concorded with those reported by El Harrak et al., 1996 in Morocco, where they noted that females were more infected than males, showing consequently, the importance of venereal transmission (De Vries and al., 1996 and Holyoak and al.,1993).

These present results were not in accordance with those of Moraillon and al.,in 1978 and Zientara et al., in 1998 in France, where no significant difference between males and females was reported, whereas Ghram and al. in 1994 found that males were more affected than females. This explains why males harboring the virus in the genital area for several years inducing a positive serological response, without any significant clinical expression, unlike females that eliminate quickly the virus after each infection. Considering the range of age, horses less than 2 years were negative, this could be linked to the fact that these young horses were not used for breeding (El Harrak and al., 1996; Moraillon and al. 1978 in Morocco).

This low number of horses of 15 does not allow us to conclude. Concerning horses with an age ranging from 4 years and more, we found a high significant difference of seropositivity. Certain authors (El Harrak and al., 1996; Lahlou, 1977; Moraillon and al., 1978; 
Ouahma, 1987), noticed a positive increase with animals age that could not be specified in our survey.

\section{CONCLUSION}

The survey showed the existence of a high rate of seropositive horses vis-à-vis to the equine viral arteritis in this region (26.31 p. Cent). This rate was significantly higher than those reported in 1986 by Choura, in 1980 and Ellouze ,Chabchoub and al., 2002 in Tunisia. In addition, the seropositivity was not significant in terms of breeds. But higher in females and old animals. In this region, the animals did not present clinical manifestations recalling viral arteritis, except of few sporadic abortions. It is recommended to make every abortion, a systematic serological research, organ sampling (liver, kidney, lung as well as runts) to search for the causative agent. Health prophylaxis remains the only effective way to cope with this disease. All these dispositions combined with a strengthening of border controls could help to control this virosis in Algeria.

\section{REFERENCES}

Balasuriya UBR., Evermann JF and Hedges JF. (1998).Serologic and molecular characterization of an abortigenic strain of equine arteritis virus isolated from infective frozen semen and an aborted equine fetus .J. Am.Vet.Med; Assoc., 21, 1586-1589.

Balasuriya UBR., Patton JF and Rossito PV.(1997).Neutralization determinants of laboratoroy strains and field isolates of equine arteritis virus: identification of four neutralization sites in the aminoterminal ectodomain of the GL envelope glycoprotein. Virology, 232,114-128.

Brion A., Fontaine $M$ and Moraillon R,(1967).Fièvre typhoïde du cheval ,artérite à virus. Rec. Méd. Vét., 143,17-27.

Cardwell JM., Wood JI., Mumford JA. Geraghty RJ. Hillyer LL and Pascoe RJ, (2002). Equine viral arteritis in the UK. Vet .Rec, 150(26), 819-820.

Chabchoub A., Ghram A., Louzir H. (1994). Maladies respiratoires du cheval situation actuelle et incidence sur l'élevage équin en Tunisie. In Journées sur les acquis de la recherche agronomique et vétérinaire. Hammamet. Tunisie, 2-4, décembre 1994.

Chabchoub A., Landolsi F., Mkaouer L., Lasfar F., Ghorbel A ., and Ghram A. (2002).Artérite à virus du cheval: enquête séro-épidémiologique dans deux régions de la Tunisie. Revue Elv.Méd vét. Pays trop, 55(2),93-97.

Choura I. (1986). Contribution à l'étude de l'artérite à virus équine dans les haras de Tunisie. Thèse doc vét. Sidi Thabet. Tunisie.
Cole J.R., Hal R.F., Gosser H.S., Hendricks J.B and Pursel AR. (1986).Transmisibility and abortogenic effect of equine viral arteritis in mares .J.Am.Vet. Med. Assoc., 189,769-777.

De Vries A.F., Rottier P.J .M. Glaser A. I., Horziner M.C (1996).Equine arteritis virus infection of equines. In :Studdert M.I..Ed., Virus infections of vertebrales .The Netherland, 171-200.

Del Piero F., Wilkins PA., Lopez JW., Glasser AL., Dubovi EJ., Schlafer DH and Lein DH (1997). Equine viral arteritis in newborn foals: clinical, pathological, serological, microbiological and immunohistochemical observations .Equine Vet.J., 29,178-185.

El Harrak M., Hmidouche A., Chakri A ., Ouragh I., BakkaliKassimi L., (1996).Epidémiologie de l'artérite à virus chez les équidés au Maroc. Prat vét Equine, 28,285292.

Ellouze MR. (1980).Contribution à l'étude épidémiologique de l'anémie infectieuse, de l'artérite à virus, de la rhinopneumonie et de la grippe équine en Tunisie. Thèse doc vét,Sidi Thabet. Tunisie.

Fukunaga Y., Matsumara T., Sugiura T., Wada R., Imagawa H ., Kanemaru T ., Kamada M,(1994). Use of the serum neutralization test for equine viral arteritis with different virus strains. Vét. Rec,134,574-576.

Ghram A ., Chabchoub A., Turki I ., Bousseta M., Ibn Amor $\mathrm{H}$ and Ghorbel a.(1994).Rhinopneumonie et artérite à virus des équidés :Enquête épidemiologique dans le Nord Est de la Tunisie.arch Ins. Pasteur Tunis, 71,512.

Holyoak GR.,Giles RC of MCCOLLUM WH.,Little TV and Timoney.(1993).Pathological changes associated with equine arthritis virus infection of the reproductive tract in and prepubertal and peripubertal colts. J Comp.Pathol. 109,281-293.

Hullinger PI., Gardner I A.,Hietala SK., Ferrero GL and MC Lachlan

Ibn Amor H. (1993). Contribution à l'étude séroépidémiologique de la rhinopneumonie et l'artérite à virus en Tunisie. Thèse doc. Vêt. Sidi Thabet. Tunisie.

Lahlou K. (1977). Enquête épidémiologique sur l'anémie infectieuse, la rhinopneumonie et l'artérite à virus des équidés au Maroc. Thèse Doc vét. IAV. Hassen II. Rabat. Maroc.

Monreal L., Villatoro A.J and Hooghus H. (1995).Clinical features of the 1992 outbreak of equine viral arteritis in Spain.Equine Vet.J, 27,301-304.

Moraillon A., Moraillon R. (1974a).Acquisitions récentes dans l'épidémiologie de l'artérite à virus du cheval en France. Rec. Méd. Vét, 150,1015-1020.

Moraillon A., Moraillon R., Toma B ., Sedrati A., and Lahlou Kassi S (1978).Enquête épidémiologique de l'anémie 
infectieuse, de l'artérite à virus, de la rhinopneumonie et de la grippe équine au Maroc. Rec. Méd. Vét, $150,921-928$.

Newton JR., Wood JLN., Castillo-Olivares FJ and Mumford JA.(1999).Serological surveillance of equine viral arteritis in the United Kingdom since the outbreak in 1993. Vet Rec, 145,511-516.

NI.(2001).Seroprevalence of antibodies against equine arteritis virus in horses residing in the United states and imported horses .J Am Vet. Med. Assoc, 219,946949.

Ouahma E. (1987). Enquête épidémiologique sur l'anémie infectieuse, la rhinopneumonie et l'artérite à virus. Rec Méd vét, 143,17-27.

Senne DA., Pearson JE and Carbrey EA. (1985). Equine viral arteritis/ a standard procedure for the virus neutralization test and comrison of results of a proficiency test performed at five laboratories.In :Proceedings of the Us Anim Health Assoc,89,29-34.

Timoney PJ ., MCCOLLUM WH. (2000b).Equine viral arteritis:Further characterization of the carrier state in stallions.J Reprod.Fertility,Suppl. 5-,3-11.
Timoney PJ and MCCOLLUM WH. (1993). Equine viral arteritis. Vet. Clin. North Am. Equine Pract.9, 295-309.

Timoney PJ and MCCOLLUM WH. (1997).Equine viral arteritis: essential facts about the disease. In: Proceedings of the $43 \mathrm{rd}$ Annu Am Assoc Equine Pract Conv, 199-201.

Timoney PJ and MCCOLLUM WH.(1986).The epidemiology of equine viral arteritis. In: Proceedings of the Am Assoc Equine Pract, 545-551.

Timoney PJ and MCCOLLUM WH.(1991). Equine viral arteritis. Current clinical and economic significance. In: Proceedings of the Am Assoc Equine Pract, 403-409.

Timoney PJ. (2000 a).Equine viral arteritis .Am.Assoc.Equine Pract.Report: 7

Timoney PJ.(1984).Clinical,virological and epidemiological features of the 1984 outbreak of equine viral arteritis in the Thoroughbred population in Kentucky,USA.Proc Int Conf Thoroughbred Breed Organ:Equine viral arteritis,24-33.

Zientara S., Labie J ., Gicquel B., Rimlinger F., Bernadac M.(1998). L'artérite virale des équidés, revue et bilan d'une enquête sérologique en France de 1996 à 1997.Point Vêt, 29,247-253. 